Sains Malaysiana 49(1)(2020): 161-168

http://dx.doi.org/10.17576/jsm-2020-4901-20

\title{
DNA Methylation of Human Choline Kinase Alpha Gene
}

(Metilasi DNA Gen Alfa Kolina Kinase Manusia)

\author{
Siti Aisyah Faten Mohamed Sa'dom, Nur Farah Hani Azemi, Mohammad Shahrizal Mohammad \\ Umar, Yoke Hiang Yee, Wei Cun See Too \& Ling Ling Few*
}

\section{ABSTRACT}

Increased level of choline kinase (CK) is a common feature in cancers and inhibition of this enzyme has been applied as anticancer strategy. DNA methylation of gene promoter especially at $C p G$ island is associated with suppression of gene expression. Despite the importance of CK especially the alpha isoform in cancer pathogenesis, epigenetic regulation of cka expression has not been investigated. Hence, this study aimed to determine the effect of DNA methylation on cka promoter activity and gene expression by using hypomethylating (5-aza) and methylating (budesonide) agents. The level of DNA methylation in the second CpG island of cka promoter was determined by PCR-based method. 5-aza and budesonide increased the methylation of the selected $C p G$ island compared to untreated control. Treatment with the drugs produced opposite effect, with 5-aza induced cka promoter activity and gene expression while budesonide suppressed the promoter activity and $m R N A$ level of this gene. Deletion of a region containing the second $C p G$ island on cka promoter resulted in significantly lower promoter activity. In conclusion, this study showed that DNA methylation could be one of the mechanisms that regulate the expression of cka gene.

Keywords: Choline kinase; DNA methylation; epigenetics; gene expression

\section{ABSTRAK}

Peningkatan tahap kolina kinase (CK) adalah ciri umum kanser dan perencatan enzim ini telah diguna sebagai strategi antikanser. Metilasi DNA promoter gen terutamanya pada pulau CpG telah dikaitkan dengan perencatan pengekspresan gen. Walaupun CK, terutamanya isoforma alfa, penting dalam patogenesis kanser, pengawalaturan epigenetik pengekspresan cka masih belum pernah dikaji. Maka, kajian ini bertujuan menentukan kesan metilasi DNA terhadap aktiviti promoter dan pengekspresan gen cka dengan menggunakan agen hipometilasi (5-aza) dan metilasi (budesonida). Tahap metilasi DNA pada pulau CpG kedua pada promoter ck $\alpha$ telah ditentukan dengan kaedah berdasarkan PCR. 5-aza dan budesonida meningkatkan tahap metilasi pulau CpG yang dikaji berbanding kawalan tanpa rawatan. Rawatan dengan agen ini menghasilkan kesan berlawanan dengan 5-aza merangsang aktiviti promoter dan pengekspresan gen cka manakala budesonida merencat aktiviti promoter dan tahap mRNA gen ini. Pemadaman salah satu kawasan yang mengandungi pulau CpG kedua pada promoter cka menyebabkan penurunan secara signifikan aktiviti promoter. Kesimpulannya, kajian ini menunjukkan metilasi DNA mungkin merupakan salah satu mekanisme yang mengawalatur pengekspresan gen $c k \alpha$.

Kata kunci: Epigenetik; kolina kinase; metilasi DNA; pengekspresan gen

\section{INTRODUCTION}

Epigenetics were described as heritable changes in gene activity without any changes in DNA sequence (Bird 2007). Study showed that abnormal epigenetic changes could cause developmental abnormalities and diseases (Hon et al. 2012). DNA methylation and histone modification are two main types of epigenetic modifications. In mammalian genome, the most common epigenetic events are DNA methylation activities. DNA methyltransferases (DNMTs) catalyse this reaction by adding a methyl group to the DNA. This reaction takes place at the 5-position (C5) of cytosine nucleotides located next to a guanine nucleotide in the DNA sequence yielding 5-methyl-cytosine (Bird 1986). Increased methylation in the promoter region of a gene usually reduces its expression, however, when the methylation occurs in the transcribed region, it can produce variable effects on gene expression (Singal et al. 2002). There are two general ways DNA methylation affect gene expression. First is by direct interference on the binding of specific transcription factors to their recognition sites in gene promoters. For example, E2F, AP-2 and NFkB transcription factors recognize the sequences where the $\mathrm{CpG}$ residues are situated. DNA methylation has been shown to inhibit the binding of these transcription factors to their target promoters (Comb \& Goodman 1990; Watt $\&$ Molloy 1988). The second mode of repression is by direct binding of specific transcriptional repressors containing methyl $\mathrm{CpG}$ binding domain (MBD) to the 
methylated DNA (Nan et al. 1998; Prokhortchouk \& Hendrich 2002). Many important cellular activities such as cancer development, cloning and transgenic technologies, viral infections, genomic imprinting, $\mathrm{X}$-inactivation and development abnormalities, have the footprints of epigenetics (Das \& Singal 2004). Currently, DNA methylation in promoter regions of tumour suppressor genes related to oncogenesis is the most extensively studied.

Choline kinase (CK) is the first enzyme in the CDPcholine pathway for biosynthesis of phosphatidylcholine, a major phospholipid in the membrane of eukaryotic cells (Lykidis et al. 2001). This enzyme catalyzes the ATP phosphorylation of choline. There are two choline kinase genes in human, $c k \alpha$ and $c k \beta$. $C k \alpha$ undergoes alternative splicing to produce $\mathrm{CK} \alpha 1$ and $\mathrm{CK} \alpha 2$ isozymes while $c k \beta$ codes for a single protein (CK $\beta$ ) (Malito et al. 2006). Increased $\mathrm{CK}$ activity has been associated with carcinogenesis (Lacal 2015). Overexpression of CK $\alpha$ in several human tumor-derived cell lines including lung, colon and prostate carcinomas has been detected (GallegoOrtega et al. 2011; Ramirez de Molina et al. 2002; Shah et al. 2010). Breast cancer resistance to drug and increased invasiveness have also been linked to CK overexpression (Shah et al. 2010). CK affects genes involve in cell proliferation, transformation, apoptosis and cell cycle (Ramirez de Molina et al. 2008). Rodriguez-Gonzalez et al. (2004) demonstrated the potential of CK $\alpha$ inhibitors as antitumor drugs in vitro and in vivo. Therefore, CK could become diagnostic indicator of cancer and marker for monitoring tumor response to therapies ( $\mathrm{Wu} \&$ Vance 2010). Gruber et al. (2012) also mentioned that the balance of CK $\alpha$ and $\beta$ isoforms was crucial for cell cycle regulation. Interestingly, the regulation of CK gene expression by epigenetic mechanism, particularly DNA methylation has never been explored.

Many researches have focused on the abnormal expression of CK $\alpha$ in different cancer cells and the potential of CK $\alpha$ inhibition as anticancer therapy. Various compounds for CK $\alpha$ inhibition have been synthesized and tested (Gomez-Peres et al. 2012). Yet, not much attention has been given to the intracellular regulation of CK gene expression, including by epigenetic mechanism.

We previously observed increased $c k \alpha$ expression in cells treated with trichostatin A (TSA), a drug that could indirectly cause DNA demethylation. Thus, this study aimed to investigate the effect of DNA methylation on $c k \alpha$ gene promoter activity and expression by utilizing 5-aza as demethylating agent and budesonide as methylating agent. The effect of these drugs on the level of DNA methylation at a selected $\mathrm{CpG}$ island on $c k \alpha$ promoter was also investigated. The results suggest the involvement of DNA methylation in $c k \alpha$ gene expression and the possible use of epigenetic drugs to suppress choline kinase activity in cancer cells.

\section{Materials AND Methods}

PREDICTION OF CPG ISLAND

$\mathrm{CpG}$ plot was used to determine the location of $\mathrm{CpG}$ islands at the $c k \alpha$ and $c k \beta$ promoters. This software is freely available at the European Molecular Biology Open Software Suite (EMBOSS) (http://www.ebi.ac.uk/emboss/ cpgplot). $\mathrm{CpG}$ island is defined as a region with more than $50 \%$ GC content and observed/expected ratio $>0.6$, covering at least $200 \mathrm{bp}$.

\section{MAMMALIAN CELL CULTURE}

HeLa cell line (ATCC no. CCL-2) was originally purchased from American Type Culture Collection (Manassas, VA, USA) and maintained at $37^{\circ} \mathrm{C}$ with $5 \% \mathrm{CO}_{2}$ in Dulbecco's Modified Eagle Medium (DMEM) (Thermo Fisher Scientific, Waltham, MA, USA) containing $10 \%$ (v/v) fetal bovine serum (Thermo Fisher Scientific, Waltham, MA, USA), $100 \mu \mathrm{g} / \mathrm{mL}$ penicillin and streptomycin (Thermo Fisher Scientific, Waltham, MA, USA). Cells were passaged at pre-confluent densities every 2 to 3 days to a maximum passage number of 20 . HeLa cells were used in this study because it has been shown to express $c k \alpha$ gene (Gruber et al. 2012).

\section{TREATMENT OF CELLS WITH EPIGENETIC DRUGS: 5-AZA (DEMETHYLATING AGENT) AND BUDESONIDE (METHYLATING AGENT)}

To manipulate the levels of DNA methylation, cells were treated with either DNA methylation inhibitor, 5'-aza (Sigma-Aldrich, St. Louis, MO, USA) or DNA methylating agent, budesonide (Sigma-Aldrich, St. Louis, MO, USA), at $7.5 \mu \mathrm{M}$ for 5-aza and $70 \mu \mathrm{M}$ for budesonide, for 12-24 h. DMSO (Sigma-Aldrich, St. Louis, MO, USA) was used to replace the epigenetic drugs in the negative control samples.

\section{QUALITATIVE ESTIMATION OF DNA METHYLATION LEVEL}

DNA methylation at specific $c k \alpha$ promoter region was estimated by Methylation Sensitive Dimethyl Sulfoxide PCR (MS-DMSO-PCR) as described by Kholod et al. (2007). The reaction mixture $(25 \mu \mathrm{L})$ contained 1.5 units KOD Hot Start DNA polymerase (Sigma-Aldrich, St. Louis, MO, USA), $1 \times$ KOD Hot Start DNA polymerase buffer, $0.4 \mu \mathrm{M}$ of each primers (as stated), $0.2 \mathrm{mM}$ of each dNTP, $1.5 \mathrm{mM}$ $\mathrm{MgCl}_{2}, 0-8 \%$ DMSO, and $25 \mathrm{ng}$ genomic DNA template. PCR was run with the following protocol: Initial denaturation at $95^{\circ} \mathrm{C}$ for $3 \mathrm{~min}$; followed with 30 cycles of denaturation at $95^{\circ} \mathrm{C}$ for $45 \mathrm{~s}$, annealing at $56^{\circ} \mathrm{C}$ for 30 $\mathrm{s}$, and extension at $72^{\circ} \mathrm{C}$ for $1 \mathrm{~min}$. The final extension was at $72^{\circ} \mathrm{C}$ for $5 \mathrm{~min}$. The PCR primers used for $c k \alpha$ promoter 
region with expected amplicon size of 216 bp were 5'-GACAGGGAAACTGAGGCTGC-3' (forward) and 5'-GCTCAGTGGGTGTGATTTTG-3' (reverse). The positive control used was $\beta$-actin and the primer sequences were 5'-CTGGGACGACATGGAGAAAA-3' (forward) and 5'-AAGGAAGGCTGGAAGAGTGC-3' (reverse). The PCR products were analyzed with $1.5 \%$ agarose gel.

\section{PCR SITE DIRECTED MUTAGENESIS OF CHOLINE KINASE PROMOTER}

Three deletion constructs of $c k \alpha$ promoter were made by PCR site directed mutagenesis according to Ho et al. (1989). The PCR protocol was as described above with full length $c k \alpha$ plasmid construct as template and no DMSO was added into the reaction. The mutated promoters were cloned into pCR2.1-TOPO vector (Thermo Fisher Scientific, Waltham, MA, USA) and confirmed by sequencing before subcloning into the firefly luciferase reporter vector, pGL4.10(luc2) (Promega, Madison, WI, USA).
TRANSFECTION AND QUANTITATION OF PROMOTER ACTIVITY BY DUAL-GLO LUCIFERASE ASSAY

Full length (2000 bp) and mutant $c k \alpha$ promoter constructs were transiently transfected into HeLa cells to investigate the importance of the deleted regions for promoter activities. Twenty-four hours prior to transfection, 0.5 - 2.0 $\times 10^{5}$ cells were seeded into each well of a 24-well dish containing $500 \mu \mathrm{L}$ of DMEM growth medium without antibiotics. The co-transfection of cells with firefly luciferase $c k \alpha$ promoter constructs and Renilla luciferase vector was done using Lipofectamine 3000 (Thermo Fisher Scientific, Waltham, MA, USA) transfection reagent. Briefly, 80 ng of pGL4.10(luc2) firefly luciferase constructs and $40 \mathrm{ng}$ of pGL4.73(hRluc/SV40) Renilla luciferase vector (Promega, Madison, WI, USA) were diluted in 50 $\mathrm{mL}$ of Opti-MEM I medium (Thermo Fisher Scientific, Waltham, MA, USA) without serum. In another tube, $1 \mu \mathrm{L}$ of Lipofectamine 3000 was also diluted in $50 \mathrm{~mL}$ of OptiMEM I medium. After $5 \mathrm{~min}$, the contents from both tubes were mixed and incubated at room temperature for $20 \mathrm{~min}$.

\section{Untreated}
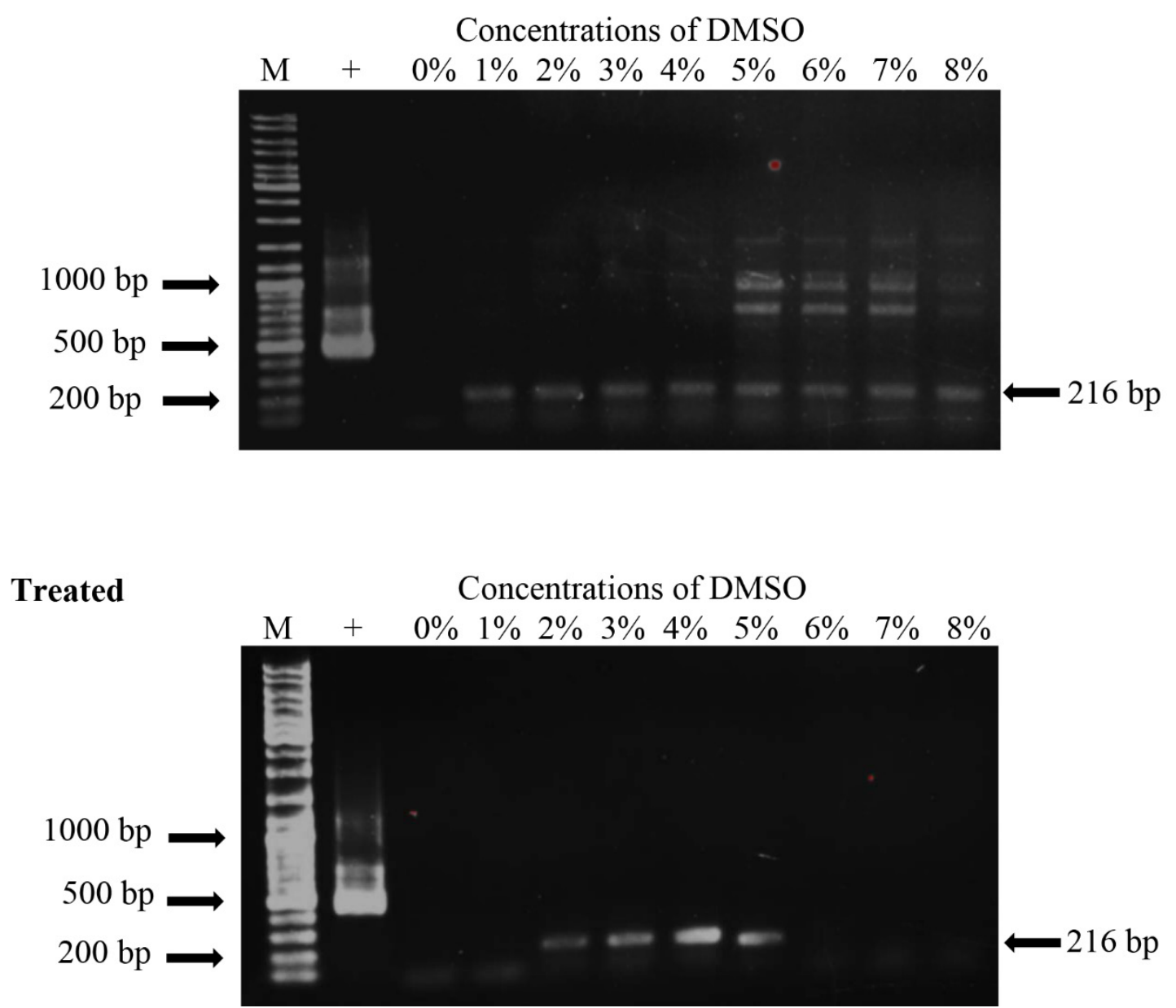

FIGURE 1. MS-DMSO-PCR of $c k \alpha \mathrm{CpG}$ island after treatment with 5-aza. PCR amplifications were performed in reactions containing the indicated DMSO concentrations with genomic DNA purified from either DMSO treated (negative control) or 5-aza $(7.5 \mu \mathrm{M})$ treated HeLa cells. M: Size marker; +: Positive control ( $\beta$-actin) 
Transfection was done by adding $100 \mathrm{~mL}$ of the mixture into each well containing cells and medium as described above followed by incubation at $37^{\circ} \mathrm{C}$ with $5 \% \mathrm{CO}_{2}$ for $48 \mathrm{~h}$.

Both firefly and control Renilla luciferase activities of the transfected cells were assayed with Dual-Glo Luciferase assay system (Promega, Madison, WI, USA) according to the manufacturer's instructions. Promoterless pGL4.10(luc2) vector was the experimental negative control, whereas the pGL4.73(hRluc/SV40) Renilla luciferase vector which was regulated by SV40 promoter was the control vector for signal normalization of each transfection assay. Promoter activity was expressed as relative firefly luciferase activity normalized to Renilla luciferase activity. The luciferase activities were measured with GloMax 20/20 luminometer (Promega, Madison, WI, USA).

QUANTIFICATION OF CKA GENE EXPRESSION BY REAL-TIME PCR

RNeasy total RNA extraction kit (Qiagen, Hilden, Germany) was used to extract the total RNA from $1 \times 10^{6}$ cells. The total RNA was converted to cDNA with RevertAid H Minus First Strand cDNA synthesis kit (Thermo Fisher Scientific, Waltham, MA, USA) according to the manufacturer's protocol. Quantitative real-time PCR (qPCR) by relative method was performed using the ABI PRISM 7000 Sequence Detection System (Thermo Fisher Scientific, Waltham, MA, USA). Each reaction consisted of $25 \mu$ L total volume containing $12.5 \mu$ L Power SYBR Green I Master Mix (Thermo Fisher Scientific, Waltham, MA, USA), $300 \mathrm{nM}$ each $c k \alpha$ specific primers (forward primer: 5'-TCAGAGCAAACATCCGGAAGT-3', reverse primer: 5'-GGCGTAGTCCATGTACCCAAAT-3', size of PCR product: $239 \mathrm{bp}$ ) or $1 \mu \mathrm{L}$ each of reference gene primers and $1 \mu \mathrm{L}$ of 1:2 diluted cDNA. Primers for the two reference genes (UBC and YWHAZ, primer sequences were not disclosed by the company) used in this study were purchased from TATAA Biocenter, Goteborg, Sweden. The settings for thermal cycling were $2 \mathrm{~min}$ at $50^{\circ} \mathrm{C}, 10 \mathrm{~min}$ at $95^{\circ} \mathrm{C}$, followed by 40 cycles of $10 \mathrm{~s}$ at $95^{\circ} \mathrm{C}$ and $1 \mathrm{~min}$ at $60^{\circ} \mathrm{C}$. Melting curve analysis was carried out at the end of a run with temperatures

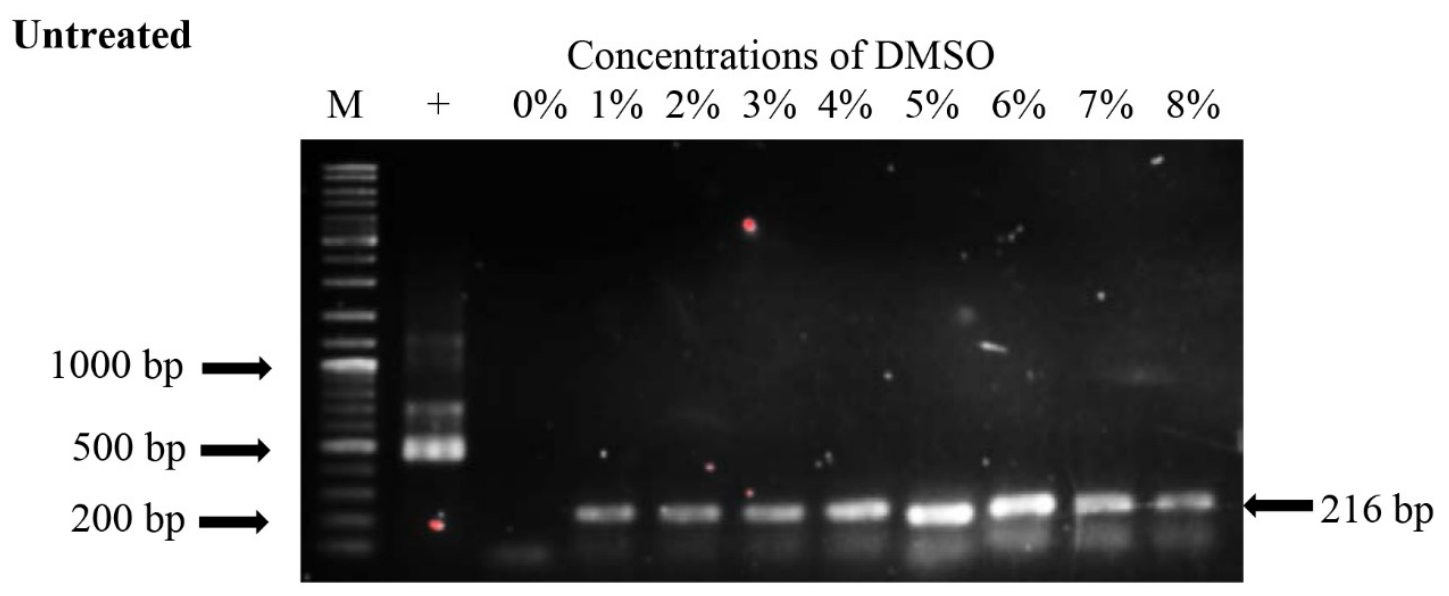

Treated

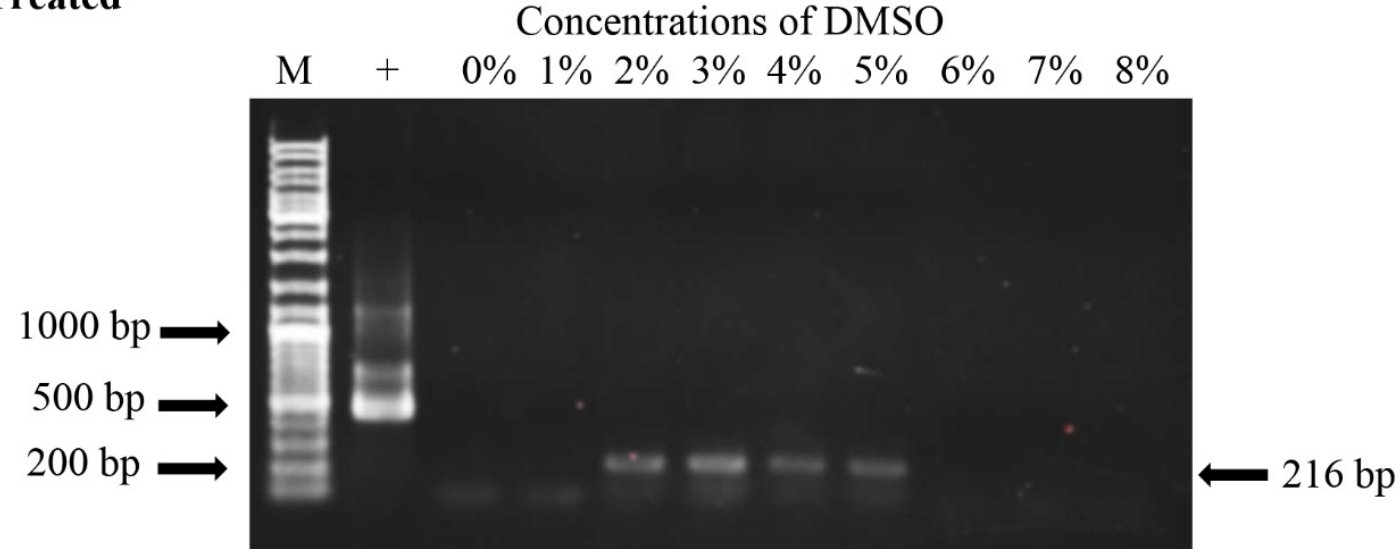

FIGURE 2. MS-DMSO-PCR of $c k \alpha \mathrm{CpG}$ island after treatment with budesonide. PCR amplifications were performed in reactions containing the indicated DMSO concentrations with genomic DNA purified from either DMSO treated (untreated) or budesonide treated HeLa cells. M: Size marker; +: Positive control ( $\beta$-actin) 

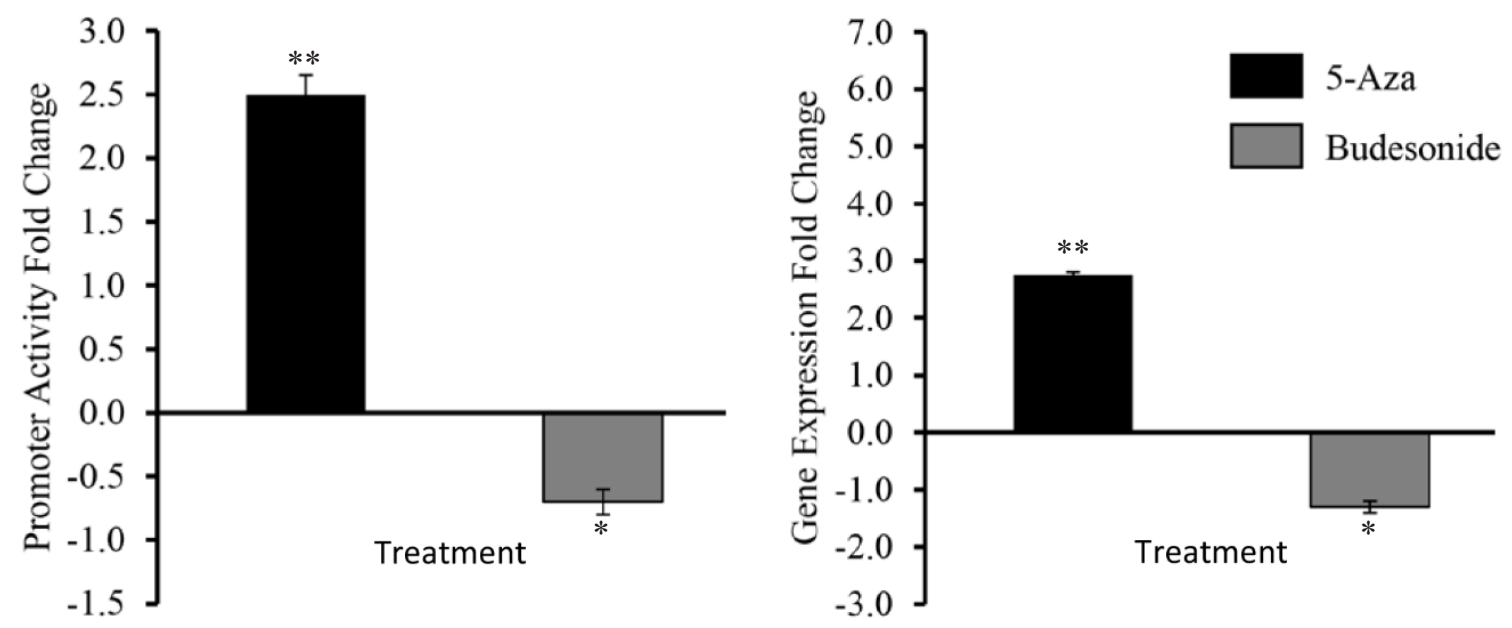

FIGURE 3. Effect of 5-aza and budesonide treatment on $c k \alpha$ promoter activity and gene expression. All data were reported as means

\pm SD. Statistical analysis was performed using independent $t$-test. $* * p<0.01$ or $* p<0.05$ vs negative control treated with DMSO

ranging from 60 to $95^{\circ} \mathrm{C}$ in $0.1^{\circ} \mathrm{C}$ increments to verify the PCR specificity.

\section{STATISTICAL ANALYSIS}

All data were analyzed using Student's t-test and one-way analysis of variance (ANOVA) with the Bonferroni post hoc test. $P<0.05$ was considered to indicate a statistically significant difference, and all analyses were performed using SPSS software version 22.0 (IBM Corp., Armonk, NY, USA). All data are presented as the mean \pm standard deviation from at least triplicates of two independent experiments.

\section{RESULTS}

EFFECT OF BUDESONIDE AND 5-AZA ON THE METHYLATION LEVEL AT SECOND CPG ISLAND, PROMOTER ACTIVITY AND EXPRESSION OF CKA GENE

Prediction with $\mathrm{CpG}$ Plot program showed that $c k \alpha$ promoter contained four putative $\mathrm{CpG}$ islands within $2000 \mathrm{bp}$ upstream from the ATG start codon. The four $\mathrm{CpG}$ islands were predicted to be located at regions between -57 and $-566,-696$ and $-908,-1383$ and -1513 , and -1595 and -1722 ( +1 denotes the first nucleotide of the ATG start codon).

MS-DMSO-PCR method was used to probe the effect of 5-aza and budesonide treatments on the methylation level of the second $\mathrm{CpG}$ island on $c k \alpha$ promoter (-908 to -696). The principle of this method is based on higher percentage of DMSO is required for PCR amplification when the level of methylation is higher. The second $\mathrm{CpG}$ island was selected for this experiment because deletion of promoter region covering this $\mathrm{CpG}$ island produced significant effect on promoter activity and a CEBP-alpha transcription factor binding site was predicted to be located in this $\mathrm{CpG}$ island by MatInspector 8.0 and TFSearch programs. Despite 5-aza being known as a demethylating agent, results in Figure 1 show that treatment with this drug increased the level of DNA methylation as the visible PCR product appeared at higher DMSO concentration ( $2 \%$, lower panel) compared to $1 \%$ DMSO (upper panel) for PCR of genomic DNA purified from negative control cells. Figure 2 shows that budesonide treatment resulted in higher level of DNA methylation as expected with visible PCR product appeared at 2\% DMSO (lower panel) compared to $1 \%$ DMSO (upper panel) for negative control.

Treatment with 5-aza significantly increased $c k \alpha$ promoter activity by about 2.5 fold $(p<0.01)$ while budesonide treatment significantly decreased the promoter activity by about 0.7 fold $(p<0.05)$ compared to control (Figure 3, left panel). 5-aza and budesonide treatment also showed similar effect on $c k \alpha$ gene expression. Treatment of 5 -aza significantly increased the level of $c k \alpha$ mRNA by 2.8 $(p<0.01)$. Conversely, budesonide treatment significantly decreased the mRNA level of $c k \alpha$ by 1.4 fold compared to negative control $(p<0.05)$ (Figure 3, right panel).

\section{IDENTIFICATION OF CKA PROMOTER REGULATORY REGIONS}

As shown in Figure 4, deletion of the region from -818 to -1790 significantly increased the $c k \alpha$ promoter activity $(p<0.001)$. The deleted region covers part of the second $\mathrm{CpG}$ island and the whole of third and fourth $\mathrm{CpG}$ islands on $c k \alpha$ promoter. Interestingly, deletion of the region from -546 to -818 (mainly located in the second $\mathrm{CpG}$ island) of $c k \alpha$ promoter resulted in significant decrease of promoter activity $(p<0.001)$. The results indicate the presence of important positive regulatory elements at the second $\mathrm{CpG}$ island, which could be modulated by DNA methylation.

\section{DISCUSSION}

CpG islands are mostly found at the 5'-end of housekeeping genes, at their promoters and transcription start sites. They are considered as gene markers because of their important 
role in gene regulation via epigenetic mechanism including DNA methylation (Du et al. 2012). DNA methylation is said to be the mechanism that represses the activity of gene promoters containing CpG islands (Deaton \& Bird 2011). $\mathrm{CpG}$ methylation causes transcription repression by direct blockage of transcription initiation complexes and recruitment of co-repressor complexes to create repressive chromatin environment (Sasai et al. 2010). Computational prediction showed four $\mathrm{CpG}$ islands in the $c k \alpha$ promoter, which suggests that DNA methylation could play significant role in the regulation of $c k \alpha$ gene expression. The importance of the second $\mathrm{CpG}$ island in $c k \alpha$ promoter was supported by the significant change in promoter activity after mutagenesis of region encompassing this $\mathrm{CpG}$ island.

In this study, two epigenetic drugs (5-aza and budesonide) have been tested to manipulate the levels of DNA methylation in the second $\mathrm{CpG}$ island of $c k \alpha$ promoter. 5-aza is an analog of cytidine that acts as hypomethylating agent. It is incorporated into cellular DNA with subsequent sequestration of DNA methyltransferases (Christman 2002). Budesonide is classified as DNA methylating agent and it has the ability to inhibit cell proliferation dependent on cell type (Liang et al. 2014). However, this study shows that 5-aza increased the level of DNA methylation in the second $\mathrm{CpG}$ island of $c k \alpha$ promoter. Previously, 5-aza also increased the expression of somatostatin (SST) gene and SST receptor 2, 4 and 5 in pancreatic ductal adenocarcinoma cell line (Gailhouste et al. 2018). Budesonide treatment produced the expected results where it increased the levels of DNA methylation in the second $\mathrm{CpG}$ island of $c k \alpha$ promoter. The results point to the potential use of budesonide to manipulate the level of DNA methylation in $c k \alpha$ gene promoter. However, it must be noted that the effect could be cell type dependent.

There are different methods to study the level of DNA methylation, in this study we have chosen the MS-DMSOPCR method to qualitatively compare the levels of DNA methylation at the selected $\mathrm{CpG}$ island before and after treatment with epigenetic drugs. This method is more simple, efficient and cost effective than bisulfite sequencing method. Real-time PCR instead of conventional PCR could be used for quantitative determination of DNA methylation level with this method. Ideally, the levels of DNA methylation after treatments with 5-aza and budesonide are also verified by other PCR-based methods applying different principles such as enrichment of 5-methylcytosine with antibodies or digestion-based assay with methylationsensitive restriction endonucleases (Kurdyukov \& Bullock 2016).

DNA methylation is usually associated with the suppression of gene expression. This is in line with our observations where budesonide decreased the promoter activity and gene expression of $c k \alpha$, possibly due to the hypermethylation induced by budesonide. Budesonide is designated as DNA methyltransferase activator (Ciechomska et al. 2019), which was used to modulate the level of DNA

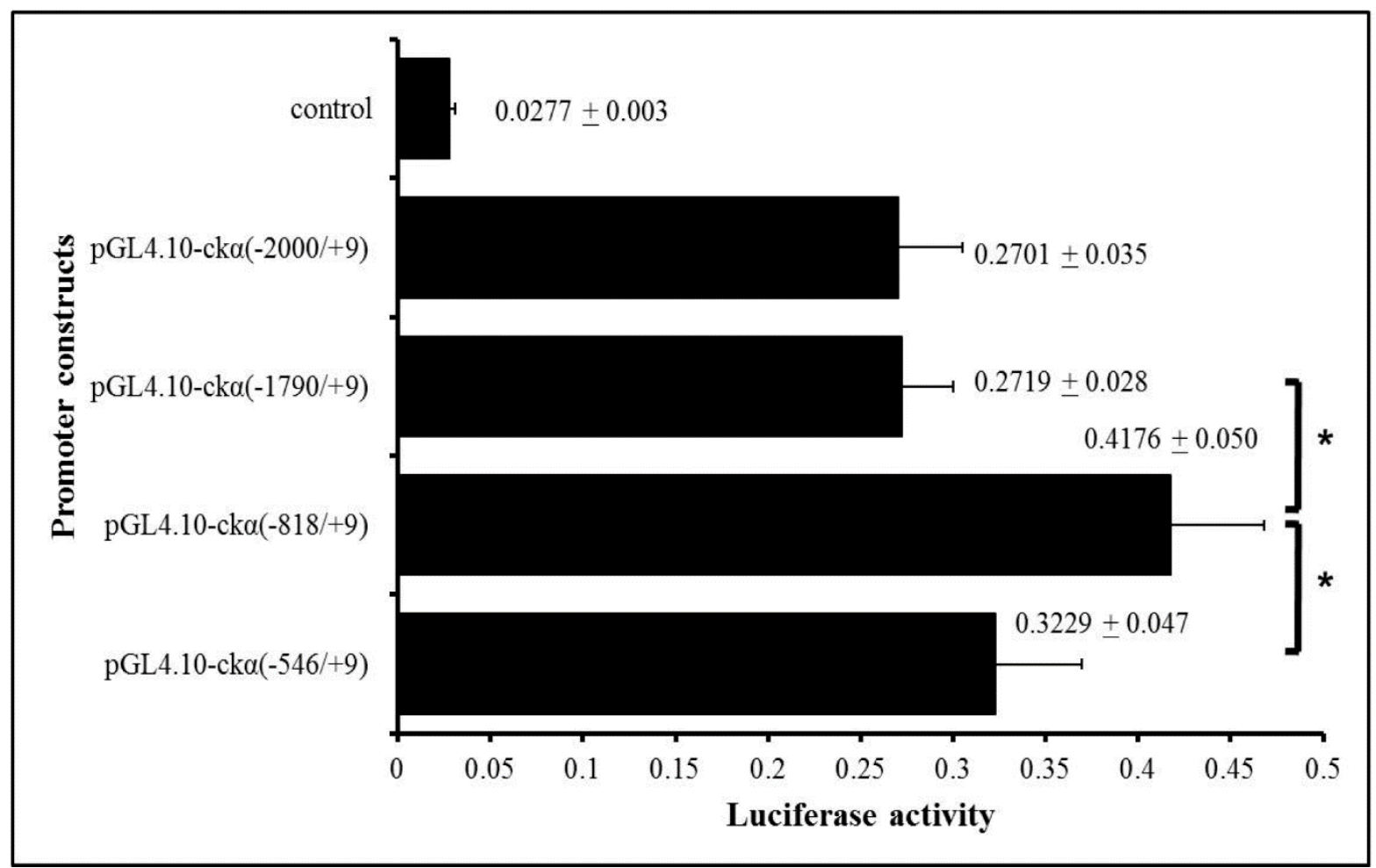

FIGURE 4. Effect of deletion mutagenesis on cka promoter activity. Promoter constructs ( $200 \mathrm{ng}$ ) were co-transfected with Renilla luciferase internal control vector $(2.5 \mathrm{ng})$ into the cells. Luciferase activities were measured by luminometer $48 \mathrm{~h}$ after transfection. All data were reported as means \pm SD. Statistical analysis was performed using one-way ANOVA and Bonferroni post hoc test. 
methylation in mouse lung tumors and alter the expressions of several cancer-related genes (Pereira et al. 2006). Budesonide has also been shown to decrease the size of non-solid nodules that may progress to adenocarcinoma of the lung (Veronesi et al. 2015). In terms of clinical significance, this study indicates the possible use of budesonide to downregulate the expression of $c k \alpha$ for anticancer therapy. More effective treatment could also be achieved by the combination of budesonide and choline kinase inhibitors, similar to the more effective prevention of mouse lung tumors with the combination of budesonide and R115777 (a farnesyl transferase inhibitor) (Alyaqoub et al. 2007).

\section{CONCLUSION}

This study showed the effect of epigenetic drugs on the methylation status of a selected $\mathrm{CpG}$ island in $c k \alpha$ promoter. The effect of these drugs on $c k \alpha$ promoter activity and expression supports the possible role of DNA methylation in regulating $c k \alpha$ gene function. A few limitations of this study that must be addressed in the future which include the use of only one cell line as well as only one 5-aza and budesonide concentrations. Yet, this work provides the first indication of a possible regulation of $c k \alpha$ gene by DNA methylation and the potential use of budesonide to modulate $c k \alpha$ expression for cancer therapy. In future, more studies are required to look at the direct effect of DNA methylation on the binding of transcription factors onto the $\mathrm{CpG}$ islands of $c k \alpha$ promoter. Mutagenesis of specific transcription factor binding sites could also be performed to obtain a better understanding of how DNA methylation regulates the expression of $c k \alpha$ gene.

\section{ACKNOWLEDGEMENTS}

This research was made possible with the financial support from Universiti Sains Malaysia Bridging Grants (304/ PPSK/6316135 and 304/PPSK/6316156). We would like to acknowledge the cooperation from staff of Tissue Culture Lab, Biomedical Lab and Molecular Biology Lab, School of Health Sciences.

\section{REFERENCES}

Alyaqoub, F.S., Tao, L., Kramer, P.M., Steele, V.E., Lubet, R.A., Gunning, W.T. \& Pereira, M.A. 2007. Prevention of mouse lung tumors and modulation of DNA methylation by combined treatment with budesonide and R115777 (Zarnestra $^{\mathrm{MT}}$ ). Carcinogenesis 28(1): 124-129.

Bird, A.P. 1986. CpG-rich islands and the function of DNA methylation. Nature 321(6067): 209-213.

Bird, A. 2007. Perceptions of epigenetics. Nature 447(7143): 396-398.

Christman, J.K. 2002. 5-Azacytidine and 5-aza-2'-deoxycytidine as inhibitors of DNA methylation: Mechanistic studies and their implications for cancer therapy. Oncogene 21(35): 5483-5495.
Ciechomska, M., Roszkowski, L. \& Maslinski, W. 2019. DNA methylation as a future therapeutic and diagnostic target in rheumatoid arthritis. Cells 8(9): E953.

Comb, M. \& Goodman, K.M. 1990. CpG methylation inhibits proenkephalin gene expression and binding of the transcription factors AP-2. Nucleic Acids Research 18(13): 3975-3982.

Das, P.M. \& Singal, R. 2004. DNA methylation and cancer. Journal Clinical Oncology 22(22): 4632-4642.

Deaton, A.M. \& Bird, A. 2011. CpG islands and regulation of transcription. Genes \& Development 25(10): 1010-1022.

Du, X., Han, L., Guo, A.Y. \& Zhao, Z. 2012. Features of methylation and gene expression in the promoter-associated $\mathrm{CpG}$ islands using human methylome data. Comparative and Functional Genomics 2(6): 775-780.

Gailhouse, L., Liew, L.C., Hatada, I., Nakagama, H. \& Ochiya, T. 2018. Epigenetic reprogramming using 5-azacytidine promotes an anti-cancer response in pancreatic adenocarcinoma cells. Cell Death and Disease 9: 468. doi: 10.1038/s41419-018-0487-z.

Gallego-Ortega, D., Gómez del Pulgar, T., Valdés-Mora, F., Cebrián, A. \& Lacal, J.C. 2011. Involvement of human choline kinase alpha and beta in carcinogenesis: A different role in lipid metabolism and biological functions. Advances in Enzyme Regulation 51(1): 183-194.

Gómez-Perez, V., McSorley, T., See Too, W.C., Konrad, M. \& Campos, J.M. 2012. Novel 4-amino bis-pyridinium and bis-quinolinium derivatives as choline kinase inhibitors with antiproliferative activity against the human breast cancer SKBR-3 cell line. ChemMedChem 7(4): 663-669.

Gruber, J., See Too, W.C., Wong, M.T., Lavie, A., McSorley, T. \& Konrad, M. 2012. Balance of human choline kinase isoforms is critical for cell cycle regulation: Implications for the development of choline kinase-targeted cancer therapy. FEBS Journal 279(11): 1915-1928.

Ho, S.N., Hunt, H.D., Horton, R.M., Pullen, J.K. \& Pease, L.R. 1989. Site-directed mutagenesis by overlap extension using the polymerase chain reaction. Gene 77(1): 51-59.

Hon, G.C., Hawkins, R.D., Caballero, O.L., Lo, C., Lister, R., Pelizzola, M., Valsesia, A., Ye, Z., Kuan, S., Edsall, L.E., Camargo, A.A., Stevenson, B.J., Ecker, J.R., Bafna, V., Strausberg, R.L., Simpson, A.J. \& Ren, B. 2012. Global DNA hypomethylation coupled to repressive chromatin domain formation and gene silencing in breast cancer. Genome Research 22(2): 246-258.

Kholod, N., Boniver, J. \& Delvenne, P. 2007. A new dimethyl sulfoxide-based method for gene promoter methylation detection. The Journal of Molecular Diagnostics 9(5): 574-581.

Kurdyukov, S. \& Bullock, M. 2016. DNA methylation analysis: Choosing the right method. Biology 9: 3. doi: 10.3390/ biology5010003.

Lacal, J.C. 2015. Choline kinase as a precision medicine target for therapy in cancer, autoimmune diseases and malaria. Precision Medicine 2: e980. doi: 10.14800/ pm.980.

Liang, H., Kowalczyk, P., Junco, J.J., Santiago, K.D., Heather, L., Malik, G., Sung-Jen, W. \& Slaga, T.J. 2014. Differential effects on lung cancer cell proliferation by agonists of glucocorticoid and PPAR $\alpha$ receptors. Molecular Carcinogenesis 53(9): 753-763.

Lykidis, A., Wang, J., Karim, M.A. \& Jackowski, S. 2001. Overexpression of a mammalian ethanolamine-specific 
kinase accelerates the CDP-ethanolamine pathway. Journal of Biological Chemistry 276(3): 2174-2179.

Malito, E., Sekulic, N., See Too, W.C., Konrad, M. \& Arnon, L. 2006. Elucidation of human choline kinase crystal structures in complex with the products ADP or phosphocholine. Journal of Molecular Biology 364(2): 136-151.

Nan, X., Ng, H.H., Johnson, C.A., Laherty, C.D., Turner, B.M., Eisenmen, R.N. \& Bird, A. 1998. Transcriptional repression by methyl-CpG-binding protein $\mathrm{MeCP} 2$ involves a histone deacetylase complex. Nature 393(6683): 386-389.

Pereira, M.A., Tao, L., Liu, Y., Li, L., Steele, V.E. \& Lubet, R.A. 2006. Modulation by budesonide of DNA methylation and mRNA expression in mouse lung tumors. International Journal of Cancer 120: 1150-1153.

Prokhortchouk, E. \& Hendrich, B. 2002. Methyl-CpG binding proteins and cancer: Are MeCpGs more important than MBDs? Oncogene 21(35): 5394-5399.

Ramirez de Molina, A., Gallego-Ortega, D., SarmenteroEstrada, J., Lagares, D., Gómez Del Pulgar, T., Bandrés, E., García-Foncillas, J. \& Lacal, J.C. 2008. Choline kinase as a link connecting phospholipid metabolism and cell cycle regulation: Implications in cancer therapy. The International Journal of Biochemistry \& Cell Biology 40(9): 1753-1763.

Ramirez de Molina, A., Gutierrez, R., Ramos, M.A., Silva, J.M., Silva, J., Bonilla, F., Sanchez, J.J. \& Lacal, J.C. 2002. Increased choline kinase activity in human breast carcinomas: Clinical evidence for a potential novel antitumor strategy. Oncogene 21(27): 4317-4322.

Rodriguez-Gonzalez, A., Ramirez de Molina, A., Fernandez, F. \& Lacal, J.C. 2004. Choline kinase inhibition induces the increase in ceramides resulting in a highly specific and selective cytotoxic antitumoral strategy as a potential mechanism of action. Oncogene 23(50): 8247-8259.

Sasai, N., Nakao, M. \& Defossez, P. 2010. Sequence-specific recognition of methylated DNA by human zinc-finger proteins. Nucleic Acids Research 38(15): 5015-5022.
Shah, T., Wildes, F., Penet, M.F., Winnard Jr., P.T., Glunde, K., Artemov, T., Ackerstaff, E., Gimi, B., Kakkad, S., Raman, V. \& Bhujwalla, Z.M. 2010. Choline kinase overexpression increases invasiveness and drug resistance of human breast cancer cells. NMR in Biomedicine 23(6): 633-642.

Singal, R., Wang, S.Z., Sargent, T., Zhu, S.Z. \& Ginder, G.D. 2002. Methylation of promoter proximal-transcribed sequences of an embryonic globin gene inhibits transcription in primary erythroid cells and promotes formation of a cell type-specific methyl cytosine binding complex. Journal of Biological Chemistry 277(3): 18971905.

Veronesi, G., Lazzeroni, M., Szabo, E., Brown, P.H., DeCensi, A., Guerrieri-Gonzaga, A., Bellomi, M., Radice, D., Grimaldi, M.C., Spaggiari, L. \& Bonanni, B. 2015. Longterm effects of inhaled budesonide on screening-detected lung nodules. Annals of Oncology 26(5): 1025-1030. doi: 10.1093/annonc/mdv064.

Watt, F. \& Molloy, P.L. 1988. Cytosine methylation prevents binding to DNA of a HeLa cell transcription factor required for optimal expression of the adenovirus major late promoter. Genes \& Development 2(9): 1136-1143.

Wu, G. \& Vance, D.E. 2010. Choline kinase and its function. Biochemistry and Cell Biology 88(4): 559-564.

School of Health Sciences

Health Campus

Universiti Sains Malaysia

16150 Kubang Kerian, Kelantan Darul Naim

Malaysia

*Corresponding author; email: fewling@usm.my

Received: 12 August 2018

Accepted: 17 October 2019 